DIVISION OF THE HUMANITIES AND SOCIAL SCIENCES CALIFORNIA INSTITUTE OF TECHNOLOGY PASADENA, CALIFORNIA 91125

DEFICITS, DEMOCRATS, AND DISTRIBUTIVE BENEFITS:

CONGRESSIONAL ELECTIONS AND THE PORK BARREL IN THE 1980s

R. Michael Alvarez

Jason Saving

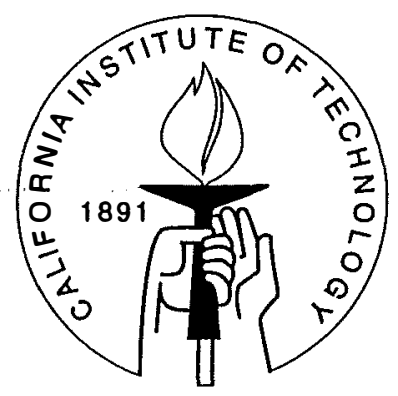

SOCIAL SCIENCE WORKING PAPER 928

May 1995 


\title{
Deficits, Democrats, and Distributive Benefits: Congressional Elections and the Pork Barrel in the $1980 \mathrm{~s}$
}

\author{
R. Michael Alvarez Jason Saving
}

\begin{abstract}
In this paper, we examine the extent to which legislators receive electoral benefits from altering the geographic distribution of federal outlays. Although there are both theoretical and anecdotal reasons to believe in the existence of such benefits, previous empirical work has largely failed to verify the connection between pork-barreling and reelection. We examine House incumbents during the 1980s, when budget deficits were allegedly forcing legislators to end the acquisition of distributive benefits, and we discover that legislators did in fact reap electoral benefits from pork-barreling in the 1980s, just as they did in the 1950s and 1960s. We further discover that there is a sharp partisan difference in the marginal effects of federal outlays: additional federal monies strongly affect Democratic reelection margins but barely impact the electoral fortunes of Republicans. This conclusion has important implications for recent debates about Congress, divided government, and the recent Republican takeover of Congress.
\end{abstract}




\title{
Deficits, Democrats, and Distributive Benefits: Congressional Elections and the Pork Barrel in the 1980s*
}

\author{
R. Michael Alvarez Jason Saving
}

As former House Speaker Tip O'Neill used to say, "All politics is local." This is usually taken to mean that representatives pay a great deal of attention to the concerns of their geographic constituents, since they wield ultimate control over a Congressional career. Paying attention to the district back home can take many forms: voting the district's interests on policy issues (Bianco 1994); being an ombudsman for constituents fighting the Washington bureaucracy (Cain, Ferejohn and Fiorina 1987); or bringing distributive benefits to the district (Ferejohn 1974).

What is surprising, however, is the lack of empirical support for a positive relationship between paying attention to the home district and incumbent reelection prospects. There is weak evidence that constituents pay attention to the legislative actions of their representatives (Alvarez and Gronke 1995; Stone 1979). Also, the evidence linking constituency service to electoral success is not strong (Cain, Ferejohn and Fiorina 1987; Johannes and McAdams 1981). Last, the evidence for political manipulations of distributive benefits is mixed (Anagnoson 1980; Chernick 1979; Gist and Hill 1984; Rundquist 1978; Rundquist and Griffith 1976).

That a strong and clear relationship between distributive benefits and electoral success has not yet been shown is even more surprising in light of recent theoretical debates about the institutional organization of Congress. Informational theories of congressional organization assert that the transmission of information is the key reason for the structure we observe in the contemporary Congress, while distributive theories assert that the structures exist to support the electoral needs of members (Krehbiel 1991; Shepsle and Weingast 1981; Weingast and Marshall 1988). Some see political manipulations of distributive benefits as a critical test between these competing models (Alvarez and Saving 1995).

${ }^{*}$ Thanks to Ken Bickers and Robert Stein for their assistance with the FAADS database. We thank John White and Abby Delman for their assistance. Alvarez thanks the John M. Olin Foundation for their support of his research through a Faculty Fellowship. The data used in this paper are available from the authors via anonymous FTP. 
In this paper we provide new evidence which strongly supports the hypothesis that House incumbents rely upon the pork barrel to facilitate their reelection bids. This is true even though we use data taken from three election cycles during the 1980's, a time when the discretionary portions of the federal budget were tightening and legislators were under fire to exercise control over an exploding budget deficit. Additionally, we show that Republicans and Democrats face different incentives with respect to the political porkbarrel, and these differences suggest that the extent to which distributive benefits are available to legislators depends upon which party holds the majority in Congress.

\section{Deficits, Democrats and the Pork Barrel}

The two classic studies of the congressional pork barrel focused on large-scale federal projects (Maas 1951; Ferejohn 1974). In these systematic studies of specific distributive policies, solid evidence of the political manipulation of these projects was found, but only through the early 1960's. Other examinations of grant programs (Arnold 1979; Plott 1968; Rundquist and Ferejohn 1975; Strom 1975) and defense programs (Goss 1972) from roughly the same time period found similar evidence of pork barreling.

But studies of later periods have had more trouble finding systematic evidence of political manipulation of distributive benefits. There is a long line of work discounting the political pork barrel (Anagnoson 1980; Chernick 1979; Gist and Hill 1984; Rundquist 1978; Rundquist and Griffith 1976). More recent analyses have disputed those conclusions, but still, in more recent time periods there is not strong evidence of congressional pork barreling (Alvarez and Schousen 1993; Bickers and Stein 1994; Feldman and Jondrow 1984; Mebane 1992).

These contradictory findings raise important questions about the ability of legislators to engage in pork barrel activities. The first of these questions focuses on the politicaleconomic context of budgetary policy. For, these studies seem to ignore the massive changes which have occurred in the process of budgeting. Before the 1974 Budget Control and Impoundment Act, the process of authorizing and appropriating allowed for changes in distributive programs without incurring significant political or economic costs (Wildavsky 1988). But after 1974, the process fell apart under the weight of Washington politics and skyrocketing entitlement spending. The added layers of complexity in the budgeting process, the increased politicization of the budget, and the increasing size of the deficits, probably placed serious constraints on opportunities for representatives to pork barrel. Thus, if opportunities to engage in distributive politics diminished after 1974, the mixed results observed in the literature make more sense.

A second question focuses on the legislators themselves, since these studies have done little to recognize that legislators differ in their abilities to engage in distributive politics. ${ }^{1}$

\footnotetext{
${ }^{1}$ Bickers and Stein (1994) rightly question studies which have not allowed for representatives to differ in their motivation for distributive benefits for their district. Alvarez and Schousen (1993) argue that
} 
As to their abilities, in any particular Congress, members will differ in the skills they use to channel disproportionate shares of distributive benefits back to their constituents. That is, via knowledge of the legislative process, or through institutional position, some representatives are better able to use the system for the benefit of the home district. In fact, members of power and constituency committees do obtain statistically higher levels of federal outlays to their districts, controlling for district demand and other political variables (Alvarez and Saving 1995).

Another major problem in this literature is the measurement of distributive benefits. One of the best definitions of distributive benefits says that they "are characterized by the ease with which they can be disaggregated and dispensed unit by small unit more or less in isolation from other units and from any general rule" (Lowi 1964, p. 690). As applied to pork barreling, distributive benefits are those obtained by representatives who use their political influence to obtain spending in their districts over and above that which they might obtain were universalistic criteria applied.

So, one issue regarding the measurement of distributive benefits is that they should be allocated through non-universalistic criteria. This implies that there are a number of federal disbursements which should not be included in measures of distributive benefits. For example, programs which are tied to economic conditions, like the various federal welfare or unemployment assistance plans, are probably not ones which should be included in measures of the pork barrel. Additionally, mandatory entitlement spending, like social security benefits, should also be excluded since these programs are administered outside the normal congressional budgetary process and are unlikely to be subject to significant political manipulation. In short, the focus should be on federal discretionary spending, which is known to be tied closely to demands for federal disbursements from geographic areas (Stein 1991; Rich 1989).

Another measurement issue arises when a particular program is initiated in a congressional district. Much of the past work in this area has focused on total spending in congressional districts in certain categories, regardless of whether a program was initiated in the current electoral cycle or decades earlier (e.g. Alvarez and Schousen 1993). However, the focus on total outlays, which includes continuing outlays from programs initiated earlier, runs the risk of biasing results towards the finding that political manipulation of distributive benefits does not occur. For example, if we look at total outlays in some congressional district in 1988 for a particular program, the total allocated would be the sum of continuing awards still in existence and new awards for the current year. If the program had been in existence since 1975, and had been allocating awards to the district since then, the awards in previous years may have been influenced by other congressional incumbents, or by the same incumbent in a different situation. This would seriously damage our chances of finding a relationship between the actions of the current

partisan images make it easier for Democratic incumbents to engage in pork barreling and to gain electoral support as a result than Republicans. A different argument is made by Alvarez and Saving (1995), who show that institutional position (mainly committee membership) plays an important role in determining the variation in distributive benefits across congressional districts. 
incumbent and the current flow of outlays to the district.

The last measurement concern is whether it is better to examine discrete program numbers, or the total amount spent in the district in each program. In Lowi's definition of distributive benefits, a critical component is the discreteness of the benefit; that is, whether it can be divided into bundles which can be allocated to certain individuals or geographic areas. This, combined with the assumption that voters are more likely to monitor the discrete numbers of programs in the district, has led some to advocate program numbers as valid measures of the federal pork barrel (Bickers and Stein 1994). However, others have asserted that voters may monitor dollar amounts instead, under the assumption that they would prefer a program in their district with a large dollar amount to a program with a small dollar amount (Alvarez and Saving 1995; Alvarez and Schousen 1993; Feldman and Jondrow 1984).

These questions in the literature about the federal pork barrel can be resolved empirically, which is the subject of the remaining sections of this paper. But first, the various criticisms leveled above about past research generate a series of hypotheses which will be tested below:

Hypothesis 1: House incumbents rely on the federal pork barrel in their bids for reelection during recent years just as they did during the 1950s and the 1960s.

Even though the budgetary game has changed since 1974, and even though the federal deficit placed serious constraints on increases in discretionary spending during the 1980s, it is quite likely that House incumbents have changed their strategies and have found ways to maintain their abilities to engage in pork barrel activities. Therefore, by providing evidence that the pork barrel positively influences incumbent reelection success during the 1980s, we will show that the reason for the contradictory findings of recent research on the pork barrel does not lie in changes in the budgetary realities of congress.

Within this hypothesis, a number of derivative hypotheses can be tested as well:

Hypothesis 1A: New outlays and programs should have a greater influence on incumbent reelection bids than outlay totals and program totals.

Hypothesis 1B: New outlays measured by dollars should have a greater influence on incumbent reelection vote margins than the sheer number of new programs.

These ancillary hypotheses all flow from the discussion above. That new outlays and program numbers should have a greater impact on incumbent reelection success relies upon the argument that the total flow of disbursements to a district or state in a particular year is really the summation of the past pork barrel activities of other incumbents or the same incumbent in possibly a different political situation. Thus, measures of new outlays or new program totals should have a stronger influence on incumbent reelection vote shares. That new outlay dollar totals matter more than the number of new programs depends upon the assertion that voters are more likely to monitor the sheer flow of money into the district, rather than the discrete number of programs. 
But, the 1994 congressional elections ended a forty-year Democratic dynasty in the House of Representatives. To an extent rarely seen in American politics, Republican challengers ran and won on a unified national platform whose rhetoric suggested that the end of pork-barrel politics was near. But is there any reason to believe that the Republicans will abolish or curtail the acquisition of distributive benefits?

Previous work suggests that the political pork-barrel will continue unabated. Distributive theory argues that Congress is characterized by a norm of universalism - that is, every representative obtains distributive benefits (Shepsle and Weingast 1981, Niou and Ordeshook 1985). To the extent that this is the case, a Republican majority should not affect the prevalence of distributive benefits. The work of congressional observers such as Fenno $(1973,1978)$ and Cain, Ferejohn and Fiorina (1987) supports the central observations of distributive theory, arguing that every representative is aided by the acquisition of distributive benefits so no representative has an incentive to abolish them. Finally, a revisionist view of political parties articulated by Cox and McCubbins (1992) holds that, while the beneficiaries of the political pork-barrel may shift from Democratic to Republican legislators, a change in party control will not endanger the pork-barrel itself:

In our view, congressional parties are a species of legislative cartel. These cartels usurp the rule-making power of the House in order to endow their members with differential power . . . and to facilitate and stabilize legislative trades that benefit their members. Most of the cartel's efforts are centered on securing control of the legislative agenda for its members (p.278).

Thus, previous work may be summarized by three statements, each of which is equivalent: that the structure of the legislature will reflect the interests of its members, that every legislator would reap electoral benefits by pork-barreling, and that no legislator would ever want to abolish the pork-barrel.

Yet, this consensus may be premature. Consider a legislature whose members belong to one of two political parties and suppose that, for whatever reason, the incumbents of one party receive more votes per dollar of pork than incumbents of the other party. Then a legislative structure designed to promote representation by members of the former party would encourage the political pork-barrel but a legislative structure designed to promote representation by members of the latter party would discourage the political pork-barrel.

In particular, suppose it were the case that Democratic incumbents receive a higher marginal benefit from pork-barreling than otherwise equivalent Republican incumbents. Then a legislative structure characterized by pork-barrel politics would tend to increase Democratic representation and decrease Republican representation. This implies that a change in majority-party status could have substantial implications for the political pork-barrel in Congress. 
We propose the following hypothesis about the electoral consequences of the pork barrel during the 1980s:

Hypothesis 2: Members of the Democratic Party will receive greater marginal electoral benefits from pork-barreling than members of the Republican Party.

This hypothesis has, as we have discussed, a great deal of relevance, both to legislative theorists and to the changes that might be wrought by a Republican Congress. Next, we turn to the research design we use to test these hypotheses.

\section{Research Design}

These hypotheses are tested in this paper with empirical models of incumbent vote shares in three electoral cycles during the 1980s. Restricting our attention to only incumbent elections during the 1980s allows for an initial test of whether the changes in the political economy of the budgetary process in recent history have influenced the ability of House members to engage in significant pork barrel activities. If the changes in the structure of the budgetary process and the constraints of an increasing budget deficit have placed serious constraints on the ability of House members to engage in pork barrel activities, we would expect to find that the amount of federal discretionary outlays to a congressional district would not factor strongly into the incumbent's vote share. But if the pork barrel is alive and well in the 1980s, this strongly suggests that members have been able to alter their strategies under the changed rules of the budget process.

Then, the ancillary hypotheses (Hypothesis $1 \mathrm{~A}$ and $1 \mathrm{~B}$ ) really are concerned with testing specifically the way in which pork barreling matters in incumbent elections. Surprisingly little is known about the empirical details of the electoral significance of congressional distributive politics, aside from recent work by Stein and Bickers (1994). Their primary contributions were to argue that the lack of strong findings in past work stem from poor specification of measures of pork barreling and from a lack of understanding of how the electorate perceives the distributive actions of their representatives. In particular, they argued that one primary flaw in past work has been that researchers have failed to consider whether the number of awards or the dollar amounts of awards are critical for incumbent electoral success. While Stein and Bickers argue for the number of new awards as the appropriate operationalization of the congressional pork barrel, they never compare empirically the effects of awards versus dollars. Neither did they test their assertion that incumbents get more bang for the buck out of new awards than for existing flows of awards. 'Both of these assertions are tested rigorously below.

\section{Measures and Analysis}

To test these hypotheses, a set of measures of distributive benefits is first required. This study draws upon the federal outlays data contained in the Federal Assistance Awards 
Data System (FAADS), originally collected by the U.S. Bureau of the Census. This database, collated and made available in a useable form by Bickers and Stein (1991), contains records of awards from each federal domestic spending program at the congressional district level, back to 1983. A wide array of information about the annual expenditures in each congressional district for each program award is available; here we draw upon a number of measures of federal outlays:

- Outlays in each district

- New outlays in each district

- Number of awards in each district

- Number of new awards in each district

In calculating each measure of outlays to each district, we included only discretionary outlays. In other words, outlays for the major entitlement programs - Social Security, Medicare, Food Stamps, and the like - are excluded from the above measures. Given they are entitlements, they should not be subject to much political manipulation once enacted, and so should not be included in measures of the pork barrel.

Also, the distinction between total outlays or awards and new outlays or awards needs to be made clearly. The former are continuing awards, which represent the annual allotments made in a district under a program which has been previously awarded. In contrast, a new award occurs once a recipient in a congressional district first is granted money under a specific program. This distinction is important since continuing outlays and awards might not measure current pork barrel activities as well as new outlays and awards (see Hypothesis 1A, above).

Table 1 describes the distribution of various measures of the political pork-barrel. As is evidenced by the table, there are enormous differentials across districts in porkbarrel expenditures. For example, the dollar value of new real outlays to districts varied from about one hundred million dollars to over five-and-a-half billion dollars, and the number of new programs to districts ranged from a mere 23 to well over seven thousand. The standard deviations (a billion dollars and seven hundred programs, respectively) demonstrate that apparent differences across districts are in fact widespread, and are not simply a function of a few outliers.

Of course, since we are examining the effects of pork barrel behavior by House incumbents on their election prospects, it is first important to specify the dependent variable in the analysis. Here, incumbent vote margins from races in which incumbents faced some challenge in three elections $(1984,1986$, and 1988) are used as the dependent variable.

Next, testing the hypotheses - all revolving around predictions about the effect of distributive benefits on incumbent election successes - outlined above requires a model 
of House elections with an appropriate set of control variables. In the literature on House elections a number of variables have been shown to have substantial influences on incumbent vote margins. To control for the effect of elite expectations we use a measure drawn from the October ratings of House races by Congressional Quarterly Weekly Review; operationalized as a seven-point scale where 1 means the challenger is thought likely to win and where 7 means the incumbent is almost certain to win, this variable should have a strong positive impact on incumbent vote margins. Also, the normal vote in a district, measured as the average of the votes received by the challenger's party in the previous Senate, House, gubernatorial and presidential elections in the past six years, should influence incumbent electoral margins negatively. The incumbent's party should also influence incumbent electoral successes; membership in the majority party (coded as a binary variable with 1 for Democrats) should increase the incumbent's vote share in this period. Next, campaign spending is an important determinant of incumbent electoral success, and we operationalize the incumbent's campaign spending share as the percentage of expenditures made by the incumbent, which should have a positive effect on incumbent vote margins. The economy is thought to affect congressional elections, and to control for that we include a measure of real income change as the change in state-level real disposable income in the past year. Further, the quality of the challenger influences the vote shares of incumbents, and we measure this with an eight-level measure of challenger quality based on their past electoral experience. With high-quality challengers given higher scores on this scale, a negative relationship between this variable and incumbent vote shares is expected. Last, a dummy variable is included in the model to control for the effects of scandal in the current electoral cycle.

These controls all form the baseline House incumbent model. Then, we add different operationalizations of pork barreling variables to test the various hypotheses about the effect of the pork barrel on incumbent vote margins. The first set of models examines the relative effectiveness of new versus existing awards, both in dollar amounts and in number of awards. Also, these models examine the relative effects of dollar amounts and numbers of awards on incumbent vote margins. The second and third sets of models, then, are similar except that the second looks at project grants and the third at formula grants. The fourth set of models examines the interaction between partisanship and pork barreling.

\section{The Pork Barrel and Incumbent Voting}

The first set of hypotheses we wish to test in this paper focus generally on whether the pork barrel is politically relevant for incumbent House members in the 1980s. The more specific hypotheses we outlined above concern the specific details of which type of pork barrel activities House incumbents get the most credit for during their reelection bids: whether existing pork barrel expenditures outweigh new expenditures; whether the electorate seems to focus on the dollars spent by the federal government in the district or the number of new projects; and last whether incumbents get electoral bang out of 
federal project grants or formula grants.

In Table 2 we present six regression models which begin to answer these questions. Here we regress the control variables described in the previous section and different specifications of total outlays and program numbers in each district. Each specification includes a different operationalization of the federal pork barrel.

Notice first that these regression results resemble closely those previously published in the literature; all of the control variables have the expected effects on House incumbent votes, and they are all estimated precisely. Additionally, the fit of the regressions is quite good, with reasonably high adjusted $R^{2}$ 's and low regression standard errors.

Next, the first four regression models in Table 2 each operationalize the federal pork barrel in different ways. Models 1 and 2 each look at the dollar totals of all existing federal programs in each district, with Model 1 including total real outlays and Model 2 only total new real outlays. Both these estimated coefficients are positive and statistically significant, showing that the federal pork barrel as measured in dollars spent in each district, did positively influence incumbent votes in the 1984, 1986 and 1988 election cycles. Additionally, notice that the estimated effectiveness of new real outlays is over twice the magnitude of total real outlays. For a typical incumbent, this result means that increasing total federal outlays to their district by one hundred million dollars translates into only .056 percent more of the vote in each election, while increasing total new outlays by the same amount would give them .17 percent more of the vote.

Then in Models 3 and 4 we have operationalized the federal pork barrel as total numbers of programs (Model 3) and total new programs (Model 4). Both of these coefficients are statistically significant and positive, meaning that numbers of new and existing programs also matter to voters during the 1980s. Here, it is interesting to compare the relative effects of existing numbers of programs with the estimated effects of new programs. In these results, the estimated effect of the number of new programs dramatically swamps that of existing programs - the estimated coefficient on number of new programs is almost five times greater than the estimated effect of all existing programs. For a typical incumbent, then, adding one thousand programs to their district yields .22 percent more of the vote; but adding one thousand new programs gives them 1.04 percent more of the vote.

So, these four regression models produce two impressive findings. First, we can clearly confirm that despite the constraints on the federal budget during the 1980s, and all of the changes to the budgetary process before and during that period, House incumbents are gaining electoral advantage by directing federal programs to their districts. There is no doubt that the federal pork barrel was alive and well during the 1980s. Second, we can also conclude that House incumbent benefit more by bringing new programs to their district than by maintaining high levels of existing programs. Across the four different operationalizations of pork barrel behavior it was clear that new programs (measured in dollars or program numbers) mattered much more for incumbent electoral success than existing programs. 
But, are voters more interested in the dollar amounts or the number of new programs? There are two ways to answer this question. The first is to use the information in Table 1 on the actual distribution of each of these operationalizations of pork barreling to see what the relative effects of new dollars and new programs are for House incumbents. During this period, a typical House incumbent receiving the minimum new dollars to her district would receive .16 percent more of the vote, while a House incumbent receiving the maximum new dollars to her district would get 9.31 percent more of the vote - a difference of 9.15 percent of the vote. On the other hand, were this incumbent to get the minimum number of new projects she would receive .02 percent more of the vote, but would receive 7.60 percent more if she had the maximum number of new programs - a differences of 7.58 percent of the vote. Clearly, across the possible range of new dollars and new numbers of programs, incumbents can get more votes by maximizing the new dollars to their district.

The second way to answer this question is to enter both new dollars and numbers of new programs into the same regression model. We do this in Models 5 and 6 of Table 2 . In both models, while the estimated effects of real outlays or real new outlays measured in dollars does not change from the estimated effects in Models 1 and 2, the estimated effects of numbers of programs and numbers of new programs do drop considerably. In fact, the estimated effects of both numbers of programs and numbers of new programs are statistically insignificant. Thus, the evidence presented in Table 2 indicates that voters seem to bring information about the dollar amounts of incumbent pork barrel activities into the voting booth and not information about the number of programs the incumbent has brought to the district.

It therefore appears that the number of programs is irrelevant to electoral success. Yet, this finding presents a sharp contrast to the work of Bickers and Stein [1994], who argue that it is the number of projects rather than the dollar amounts of those projects that influence voters. Given this, we decided to test the proper functional form of the two variables using the Box-Cox technique. ${ }^{2}$ The test revealed an interesting difference between these variables, suggesting a linear formulation (parameter value of 0.88 ) for new dollars but a logged formulation (parameter value of 0.00 ) for new programs. Further regressions using the logged number of new programs in place of the number of new dollars yielded results that were qualitatively identical to the results of Table 2 , and a combined regression similar to Model 6 of Table 2 revealed that both variables were highly significant. A summary of these results is presented in Table 3.

${ }^{2}$ The Box-Cox technique estimates a form of the linear regression model:

$$
y=\alpha+\beta g(x)+\varepsilon
$$

where

$$
g^{\lambda}(x)=\frac{x^{\lambda}-1}{\lambda}
$$

The Box-Cox technique estimates $\lambda$, and that parameter gives the functional form for the particular $x$ variable (or set of $x$ 's). If $\lambda=1$, the functional form is linear; if $\lambda=0$, the functional form is $\log$-linear; and if $\lambda=-1$, the functional form is the reciprocal of $x$. 
When both new dollars and logged new programs are included in a regression, as in the case of Model 10 of Table 3, both variables attain statistical significance. There are two possibilities about the true relationship between these variables: either they measure two distinct aspects of pork-barrel politics or else they measure the same aspect with different random shocks incorporated within them. Each of these possibilities is problematic for statistical analysis. If the variables measure different aspects of pork-barrel politics, then new dollars and logged new programs have qualitatively different effects on voters, and both should be included in statistical regressions. It is of course possible to develop stylized facts about this result, but there is neither theoretical nor anecdotal support for such a differentiation. If the two variables actually measure the same underlying aspect of pork-barrel politics, then the inclusion of both variables in statistical regressions could be a misspecification and any statistical inferences drawn from these regressions might be flawed. The results in Model 10 are consistent with both accounts, so in this form the data do not seem able to discriminate between explanations. However, one aspect of the estimated effects of new outlays and numbers of new programs in Model 10 is promising - when we use the appropriate functional form for numbers of new programs (log-linear), this parameter becomes statistically significant, in contrast to the result in Model 6 (Table 2). We believe that this tips the scales towards the idea that these two variables measure different components of the political pork barrel; but further work is needed on this question.

In order to test Hypothesis 2 (partisan heterogeneity in the effects of the pork barrel on incumbent election outcomes), we split our sample used in the previous regression models by political party and then compare the estimated coefficients across the two samples. These results are given in Table 4.

The results of this table confirm the hypothesis that the political pork-barrel provided disproportionate electoral support to Democrats during the 1980s. The marginal effect of an additional dollar of federal outlays on incumbent vote share was approximately twice as large for Democratic incumbents as Republican incumbents. In fact, not one of the Republican coefficients were statistically significant at the .10 level, which means we cannot reject the hypothesis that Republicans reaped no gains from pork-barrel politics during the 1980s. While it may be premature to conclude that Republicans do not benefit from the political pork-barrel, it seems clear that Republican incumbents were less dependent on the pork-barrel system than were incumbent Democrats during the 1980s, when the Democrats were the House majority party.

It is reasonable to ask whether this analysis suggests that the new Republican Congress will curtail or eliminate the political pork-barrel. After all, if such an action would tend to increase Republican representation in Congress, why wouldn't the Republicans choose to pursue it? The answer lies in the self-interest of Republican incumbents. Before a Republican challenger is elected to Congress (i.e. when he is a candidate), he has no reason to support the continuation of pork-barrel politics because he cannot obtain any pork for himself and he recognizes that abolition of the system is in the long-term interest of the Republican party and Republican ideals. However, the calculus shifts when 
the Republican challenger finds himself elected to Congress. He discovers that he can in fact reap electoral benefits through the political pork-barrel (although an otherwise identical Democrat would reap larger benefits) and that he would in fact incur electoral costs through the abolition of the political pork-barrel (although an otherwise identical Democrat would incur larger costs). Thus, while the abolition of the pork-barrel might well benefit the Republican party, the prospect of increased Republican representation in Congress may provide little comfort to the Republican incumbents who must voluntarily lessen their own probabilities of reelection in order to bring about such an increase.

\section{Discussion}

The results in Table 4 demonstrate that the politics of the pork barrel during the 1980s were crucially dependent on the political party of the officeholder. Democratic incumbents strongly benefited from the pork barrel, while Republicans benefited weakly or not at all. These findings speak to two important and related debates in the literature on Congress and legislative-executive relations.

First, there has been a resurgence of interest in the power of the majority party in Congress (Cox and McCubbins 1992; Kiewiet and McCubbins 1991). Our findings can be interpreted as a demonstration of one aspect of the power of the majority party the ability to direct disproportionate shares of distributive benefits to the districts of partisans. What we might be observing is some form of an equilibrium outcome, in which members of the House majority party receive greater distributive benefits than minority partisans and use those benefits to enhance their relations with constituents.

This, however, is similar to arguments advanced by Jacobson (1990) to explain divided government. He argued that "Congressional candidates are evaluated on their personal character and experience and on their devotion to district services and local issues" (1990: 115), which Democrats are particularly successful at exploiting. So, our results provide support for such a view on divided government (Alvarez and Schousen 1993), in contrast to the arguments advanced by Fiorina (1988).

But our findings also suggest that the two political parties may have differential incentives to continue the system of pork-barrel politics that has characterized the modern House, although it need not be the case that members of the new Republican Congress will actually vote to curtail the political pork barrel. We have provided substantial evidence that the pork barrel survived the changes in the process of budgeting and the constraints imposed on the budget by the huge deficits of the 1980s. Many have remarked at how successful the Republicans seem to have been in constraining the ability of Congress to use discretionary expenditures for political gain in the 1980s. Indeed, the results of our paper suggest a reason for them to do so - curtailment of the political pork-barrel will inflict disproportionate electoral harm on Democratic incumbents. However, our results do show that House incumbents have adjusted to the new realities of budget politics, and 
that in many instances pork-barrel expenditures continue to be obtained and continue to influence the reelection prospects of incumbent legislators.

What remains to be seen, however, is whether these same findings will hold with a reorganized Congressional institution and a new majority party in the House. Will the new House majority resist the temptation to use their new-found institutional power to bring home the the bacon to their constituents? Will the pork barrel wither and die under dramatic budget cuts? We are in the midst of a wonderful natural experiment, and within a few years we should be in a good position to examine again the effects of party and institution on the distribution of federal expenditures across Congressional districts. 
Table 1:

\begin{tabular}{lcccc} 
Measure & Mean & Min. & Max. & S.D. \\
\hline Real Outlays & 22.8 & 6.98 & 126.5 & 11.6 \\
New Real Outlays & 8.13 & .96 & 55.1 & 5.00 \\
Number of Programs & 1.89 & .086 & 19.1 & 2.03 \\
Number of New Programs & .63 & .023 & 7.31 & .71 \\
Real Project Outlays & .90 & .002 & 13.1 & 1.16 \\
New Real Project Outlays & .45 & 0 & 9.98 & .65 \\
Number of Project Programs & .46 & .005 & 7.32 & .56 \\
Number of New Project Programs & .23 & .002 & 5.06 & .30 \\
Real Grant Outlays & 3.60 & .37 & 58.1 & 5.50 \\
New Real Grant Outlays & .99 & 0 & 24.7 & 1.86 \\
Number of Grant Programs & .47 & .001 & 14.9 & .85 \\
Number of New Grant Programs & .07 & 0 & 1.58 & .15 \\
\hline Note: Dollar amounts are in 100 millions; numbers of projects are \\
in thousands.
\end{tabular}


Table 2: House Incumbent Vote, 1984-1988; Federal Outlays (Monies and Program Totals by District)

\begin{tabular}{|c|c|c|c|c|c|c|}
\hline & Model 1 & Model 2 & Model 3 & Model 4 & Model 5 & Model 6 \\
\hline \multirow[t]{2}{*}{ Intercept } & $66.0^{* *}$ & $65.9^{* *}$ & $66.6^{* *}$ & $66.2^{* *}$ & $66.0^{* *}$ & $65.9^{* *}$ \\
\hline & 1.86 & 1.83 & 1.83 & 1.83 & 1.86 & 1.84 \\
\hline \multirow{2}{*}{$\begin{array}{l}\text { Real Outlays } \\
\text { (100 Millions) }\end{array}$} & $.056^{* *}$ & & & & $.056^{* *}$ & \\
\hline & .018 & & & & .027 & \\
\hline \multirow{2}{*}{$\begin{array}{l}\text { New Real Outlays } \\
\text { (100 Millions) }\end{array}$} & & $.169^{* *}$ & & & & $.132 * *$ \\
\hline & & .042 & & & & .063 \\
\hline \multirow{2}{*}{$\begin{array}{l}\text { Number of Programs } \\
\text { (Thousands) }\end{array}$} & & & $.22^{* *}$ & & .002 & \\
\hline & & & .10 & & .15 & \\
\hline \multirow{2}{*}{$\begin{array}{l}\text { Number of New Programs } \\
\text { (Thousands) }\end{array}$} & & & & $1.04^{* *}$ & & .35 \\
\hline & & & & .30 & & .44 \\
\hline \multirow[t]{2}{*}{ CQ Fall Rating } & $.71^{* *}$ & $.73^{* *}$ & $.70^{* *}$ & $.70^{* *}$ & $.71^{* *}$ & $.72^{* *}$ \\
\hline & .19 & .19 & .19 & .19 & .19 & .19 \\
\hline \multirow[t]{2}{*}{ Normal Vote } & $-.40 * *$ & $-.39 * *$ & $-.39 * *$ & $-.39 * *$ & $-.40 * *$ & $-.39 * *$ \\
\hline & .02 & .02 & .02 & .02 & .02 & .02 \\
\hline \multirow[t]{2}{*}{ Inc. Party } & $.71^{* *}$ & .62 & $.78^{* *}$ & $.71^{*}$ & $.71^{*}$ & .63 \\
\hline & .40 & .40 & .40 & .40 & .40 & .40 \\
\hline \multirow[t]{2}{*}{ Inc. Spending Share } & $24.2^{* *}$ & $24.1^{* *}$ & $24.3^{* *}$ & $24.4^{* *}$ & $24.2^{* *}$ & $24.2^{* *}$ \\
\hline & 1.30 & 1.29 & 1.30 & 1.30 & 1.30 & 1.30 \\
\hline \multirow[t]{2}{*}{ Real Income } & $.19^{* *}$ & $.17^{*}$ & $.20^{* *}$ & $.20^{* *}$ & $.19^{* *}$ & $.18^{*}$ \\
\hline & .09 & .09 & .09 & .09 & .09 & .09 \\
\hline \multirow[t]{2}{*}{ Chal. Quality } & $-1.13^{* *}$ & $-1.14^{* *}$ & $-1.15^{* *}$ & $-1.15^{* *}$ & $-1.13^{* *}$ & $-1.14^{* *}$ \\
\hline & .19 & .19 & .19 & .19 & .19 & .19 \\
\hline \multirow[t]{2}{*}{ Scandal } & $-8.37^{* *}$ & $-8.26^{* *}$ & $-8.32^{* *}$ & $-8.33^{* *}$ & $-8.37^{* *}$ & $-8.28 * *$ \\
\hline & 1.40 & 1.39 & 1.40 & 1.40 & 1.40 & 1.40 \\
\hline \multirow[t]{2}{*}{1984 Intercept } & $2.20^{* *}$ & $1.56^{* *}$ & $2.21^{* *}$ & $2.08^{* *}$ & $2.20^{* *}$ & $1.68^{* *}$ \\
\hline & .53 & .54 & .54 & .53 & .54 & .56 \\
\hline \multirow[t]{2}{*}{1986 Intercept } & $1.41^{* *}$ & $1.11^{* *}$ & $1.29^{* *}$ & $1.12^{* *}$ & $1.41^{* *}$ & $1.08^{* *}$ \\
\hline & .48 & .48 & .48 & .48 & .48 & .48 \\
\hline Number of Cases & 984 & 984 & 984 & 984 & 984 & 984 \\
\hline ADJ-R ${ }^{2}$ & .61 & .61 & .61 & .61 & .60 & .61 \\
\hline Mean Inc. Vote & 67.7 & 67.7 & 67.7 & 67.7 & 67.7 & 67.7 \\
\hline $\mathrm{SE}$ & 5.83 & 5.81 & 5.85 & 5.82 & 5.84 & 5.81 \\
\hline
\end{tabular}

Note: Entries are regression coefficients followed by standard errors. Monetary outlays are measured in millions; numbers of projects in thousands. The dependent variable is incumbent share of the two-party vote and the other variables are defined in the text. "**" denotes an estimate statistically significant at the $\mathrm{p}=.05$ level and "*" at the $\mathrm{p}=.10$ level, both two-tailed tests. 
Table 3: House Incumbent Vote, 1984-1988, with Logged Programs

\begin{tabular}{|c|c|c|c|c|c|c|}
\hline & Model 1 & Model 2 & Model 7 & Model 8 & Model 9 & Model 10 \\
\hline \multirow[t]{2}{*}{ Intercept } & $66.0^{* *}$ & $65.9^{* *}$ & $60.4^{* *}$ & $61.0^{* *}$ & $61.3^{* *}$ & $62.2^{* *}$ \\
\hline & 1.86 & 1.83 & 2.59 & 2.33 & 2.69 & 2.43 \\
\hline \multirow{2}{*}{$\begin{array}{l}\text { Real Outlays } \\
\text { (100 Millions) }\end{array}$} & $.056^{* *}$ & & & & .027 & \\
\hline & .018 & & & & .022 & \\
\hline \multirow{2}{*}{$\begin{array}{l}\text { New Real Outlays } \\
\text { (100 Millions) }\end{array}$} & & $.169 * *$ & & & & $.097^{*}$ \\
\hline & & .042 & & & & .053 \\
\hline \multirow{2}{*}{$\begin{array}{l}\text { Logged Programs } \\
\text { (Thousands) }\end{array}$} & & & $.87^{* *}$ & & $.70^{* *}$ & \\
\hline & & & .24 & & .29 & \\
\hline \multirow{2}{*}{$\begin{array}{l}\text { Logged New Programs } \\
\text { (Thousands) }\end{array}$} & & & & $0.94^{* *}$ & & $.64^{* *}$ \\
\hline & & & & .22 & & .28 \\
\hline \multirow[t]{2}{*}{ CQ Fall Rating } & $.71^{* *}$ & $.73^{* *}$ & $.70^{* *}$ & $.70^{* *}$ & $.70 * *$ & $.72^{* *}$ \\
\hline & .19 & .19 & .19 & .19 & .19 & .19 \\
\hline \multirow[t]{2}{*}{ Normal Vote } & $-.40 * *$ & $-.39 * *$ & $-.39 * *$ & $-.39 * *$ & $-: 39 * *$ & $-.39 * *$ \\
\hline & .02 & .02 & .02 & .02 & .02 & .02 \\
\hline \multirow[t]{2}{*}{ Inc. Party } & $.71^{*}$ & .62 & $.78^{* *}$ & $.72 *$ & $.74^{*}$ & .64 \\
\hline & .40 & .40 & .40 & .39 & .40 & .40 \\
\hline \multirow[t]{2}{*}{ Inc. Spending Share } & $24.2^{* *}$ & $24.1^{* *}$ & $24.5^{* *}$ & $24.5^{* *}$ & $24.5^{* *}$ & $24.4^{* *}$ \\
\hline & 1.30 & 1.29 & 1.30 & 1.29 & 1.30 & 1.29 \\
\hline \multirow[t]{2}{*}{ Real Income } & $.19^{* *}$ & $.17^{*}$ & $.21^{* *}$ & $.21^{* *}$ & $.20 * *$ & $.19^{*}$ \\
\hline & .09 & .09 & .09 & .09 & .09 & .09 \\
\hline \multirow[t]{2}{*}{ Chal. Quality } & $-1.13^{* *}$ & $-1.14^{* *}$ & $-1.15^{* *}$ & $-1.16^{* *}$ & $-1.14^{* *}$ & $-1.15^{* *}$ \\
\hline & .19 & .19 & .19 & .19 & .19 & .19 \\
\hline \multirow[t]{2}{*}{ Scandal } & $-8.37^{* *}$ & $-8.26^{* *}$ & $-8.41^{* *}$ & $-8.32^{* *}$ & $-8.42^{* *}$ & $-8.29 * *$ \\
\hline & 1.40 & 1.39 & 1.40 & 1.39 & 1.40 & 1.39 \\
\hline \multirow[t]{2}{*}{1984 Intercept } & $2.20^{* *}$ & $1.56^{* *}$ & $2.62^{* *}$ & $2.19 * *$ & $2.58^{* *}$ & $1.88^{* *}$ \\
\hline & .53 & .54 & .55 & .53 & .55 & .55 \\
\hline \multirow[t]{2}{*}{1986 Intercept } & $1.41^{* *}$ & $1.11^{* *}$ & $1.17^{* *}$ & $1.03^{* *}$ & $1.23^{* *}$ & $0.99 * *$ \\
\hline & .48 & .48 & .48 & .48 & .48 & .48 \\
\hline Number of Cases & 984 & 984 & 984 & 984 & 984 & 984 \\
\hline ADJ-R ${ }^{2}$ & .61 & .61 & .61 & .61 & .61 & .61 \\
\hline Mean Inc. Vote & 67.7 & 67.7 & 67.7 & 67.7 & 67.7 & 67.7 \\
\hline $\mathrm{SE}$ & 5.83 & 5.81 & 5.82 & 5.82 & 5.82 & 5.80 \\
\hline
\end{tabular}

Note: Entries are regression coefficients followed by standard errors. Monetary outlays are measured in millions; numbers of projects in thousands. The dependent variable is incumbent share of the two-party vote and the other variables are defined in the text. "**" denotes an estimate statistically significant at the $\mathrm{p}=.05$ level and "*" at the $\mathrm{p}=.10$ level, both two-tailed tests. 
Table 4: House Incumbent Vote, 1984-1988; New Federal Outlays and Majority Party Status (New Monies and New Program Totals by District)

\begin{tabular}{|c|c|c|c|c|c|c|}
\hline & Dem & Rep & Dem & Rep & Dem & Rep \\
\hline \multirow[t]{2}{*}{ Intercept } & $70.1^{* *}$ & $54.3^{* *}$ & $63.4^{* *}$ & $51.5^{* *}$ & $64.1^{* *}$ & $52.6^{* *}$ \\
\hline & 2.17 & 2.66 & 2.83 & 3.40 & 2.99 & 3.60 \\
\hline New Real Outlays & $.173^{* *}$ & 103 & & & .050 & .074 \\
\hline (100 Millions) & .055 & .065 & & & .069 & .079 \\
\hline \multirow[t]{2}{*}{ Logged New Programs } & & & $1.22^{* *}$ & .48 & $1.05^{* *}$ & .27 \\
\hline & & & .29 & .33 & .36 & .40 \\
\hline \multirow[t]{2}{*}{ CQ Fall Rating } & .41 & $.80^{* *}$ & .32 & $.81^{* *}$ & .34 & $.81^{* *}$ \\
\hline & .26 & .26 & .26 & .26 & .26 & .26 \\
\hline \multirow[t]{2}{*}{ Normal Vote } & $-.43 * *$ & $-.27^{* *}$ & $-.43 * *$ & $-.26 * *$ & $-.34^{* *}$ & $-.81^{* *}$ \\
\hline & .03 & .04 & .03 & .04 & .03 & .04 \\
\hline \multirow[t]{2}{*}{ Inc. Spending Share } & $20.1^{* *}$ & $31.5^{* *}$ & $20.5^{* *}$ & $31.7^{* *}$ & $20.4^{* *}$ & $31.6^{* *}$ \\
\hline & 1.63 & 1.99 & 1.62 & 2.00 & 1.62 & 2.00 \\
\hline \multirow[t]{2}{*}{ Real Income } & $.27^{*}$ & -.02 & $.28^{* *}$ & .01 & $.28^{* *}$ & -.01 \\
\hline & .13 & .12 & .13 & .12 & .13 & .13 \\
\hline \multirow[t]{2}{*}{ Chal. Quality } & $-1.23^{* *}$ & $-.83^{* *}$ & $-1.22^{* *}$ & $-.86^{* *}$ & $-1.22^{* *}$ & $-.84^{* *}$ \\
\hline & .26 & .25 & .26 & .25 & .26 & .25 \\
\hline \multirow[t]{2}{*}{ Scandal } & $-8.88^{* *}$ & $-8.21^{* *}$ & $-8.94^{* *}$ & $-8.29^{* *}$ & $-8.93^{* *}$ & $-8.21^{* *}$ \\
\hline & 1.67 & 2.41 & 1.66 & 2.41 & 1.66 & 2.41 \\
\hline \multirow[t]{2}{*}{1984 Intercept } & -.31 & $3.73^{* *}$ & .44 & $4.05^{* *}$ & .26 & $3.85^{* *}$ \\
\hline & .71 & .75 & .70 & .74 & .74 & .77 \\
\hline \multirow[t]{2}{*}{1986 Intercept } & $2.02^{* *}$ & .01 & $2.00^{* *}$ & -.09 & $1.94^{* *}$ & -.06 \\
\hline & .66 & .68 & .65 & .69 & .65 & .69 \\
\hline Number of Cases & 560 & 424 & 560 & 424 & 560 & 424 \\
\hline ADJ-R ${ }^{2}$ & .64 & .64 & .64 & .63 & .64 & .63 \\
\hline Mean Inc. Vote & 67.9 & 67.6 & 67.9 & 67.6 & 67.9 & 67.6 \\
\hline $\mathrm{SE}$ & 5.93 & 5.20 & 5.88 & 5.21 & 5.89 & 5.21 \\
\hline
\end{tabular}

Note: Entries are regression coefficients followed by standard errors. Monetary outlays are measured in millions; numbers of projects in thousands. The dependent variable is incumbent share of the two-party vote and the other variables are defined in the text. "**" denotes an estimate statistically significant at the $\mathrm{p}=.05$ level and "** at the $\mathrm{p}=.10$ level, both two-tailed tests. 


\section{References}

Alvarez, R.M. and P. Gronke. 1995. "Constituents and Legislators: Learning About the Persian Gulf War Resolution." Legislative Studies Quarterly, forthcoming.

Alvarez, R.M. and J. Saving. 1995. "Congressional Committees and the Political Economy of Federal Outlays." Public Choice, forthcoming.

Alvarez, R.M. and M.M. Schousen. 1993. "Policy Moderation or Conflicting Expectations? Testing the Intentional Models of Split-Ticket Voting." American Politics Quarterly 21: 410-428.

Anagnoson, J. T. (1980). Politics in the Distribution of Federal Grants: The Case of the Economic Development Administration. In B. S. Rundquist, Political Benefits. Lexington, MA: Lexington Books.

Arnold, R. D. (1979). Congress and the Bureaucracy. New Haven: Yale University Press.

Bianco, W.T. 1994. Trust: Representatives and Constituents. Ann Arbor, MI: University of Michigan Press.

Bickers, K. N. and R.M. Stein. 1991. U.S. Domestic Assistance Programs Database. Mimeo. Bloomington, IN: Indiana University.

Bickers K.N. and R.M. Stein. 1994. "Congressional Elections and the Pork Barrel." Journal of Politics 56: 377-399.

Cain, B., J. Ferejohn and M. Fiorina. 1987. The Personal Vote: Constituency Service and Electoral Independence. Cambridge: Harvard University Press.

Chernick, H.A. 1979. "An Economic Model of the Distribution of Project Grants." In P. Mieszkowski and W. H. Oakland, Fiscal Federalism and Grants-in-Aid. Washington, D.C.: Urban Institute.

Cox, G.W. and M.D. McCubbins. 1992. Legislative Leviathan: Party Government in the House. Berkeley: University of California Press.

Feldman, P. and Jondrow, J. (1984). Congressional Elections and Local Federal Spending. American Journal of Political Science 28: 147-163.

Fenno, R. F. (1973). Congressmen in Committees. Boston: Little, Brown.

Fenno, R.F. (1978). Home Style: House Members in Their Districts. New York: HarperCollins Publishers.

Ferejohn, J. A. 1974. Pork Barrel Politics: Rivers and Harbors Legislation, 1947-1968. Stanford, CA: Stanford University Press. 
Fiorina, M. P. 1988. "The Reagan Years: Turning to the Right or Groping Toward the Middle?" In The Resurgence of Conservativism in Anglo-American Democracies, edited by Barry Cooper, Allan Kornberg, and William Mishler. Durham, NC: Duke University Press.

Gist, J. R. and Hill, R. C. (1984). Political and Economic Influences on the Bureaucratic Allocation of Federal Funds: The Case of Urban Development Action Grants. Journal of Urban Economics 16: 158-172.

Goss, C. F. (1972). Military Committee Membership and Defense-Related Benefits in the House of Representatives. Western Political Quarterly 25: 215-261.

Jacobson, G.C. 1990. The Electoral Origins of Divided Government. Boulder, CO: Westview Press.

Johannes, J.R. and J.C. McAdams. 1981. "The Congressional Incumbency Effect: Is It Casework, Policy Compatibility, or Something Else?" American Journal of Political Science 25: 512-538.

Kiewiet, D.R. and M.D. McCubbins. 1991. The Logic of Delegation: Congressional Parties and the Appropriations Process. Chicago: The University of Chicago Press.

Krehbiel, K. (1991). Information and Legislative Organization. Ann Arbor, MI: University of Michigan Press.

Lowi, T. (1964). American Business, Public Policy, Case Studies, and Political Theory. World Politics 15: 677-715.

Maas, A. 1951. Muddy Waters. Cambridge: Harvard University Press.

Mebane, W. R. 1992. Congressional Campaign Finance and the Pork Barrel. Mimeo. Ithaca, NY: Cornell University.

Niou, E. and P. Ordeshook. 1985. Universalism in Congress. American Journal of Political Science. 29: 246-290.

Plott, C. 1968. Some Organizational Influences of Urban Renewal Decisions. American Economic Review 58: 306-321.

Rich, M. J. 1989. Distributive Politics and the Allocation of Federal Grants. American Political Science Review 83: 193-213.

Rundquist, B. S. and Ferejohn, J. A. (1975). Observations on A Distributive Theory of Policy-Making: Two American Expenditure Programs Compared. In C. Liske, W. Loehr, and J. McCamant, Comparative Public Policy. New York: John Wiley.

Rundquist, B. S. and Griffith, D. E. (1976). An Interrupted Time-Series Test of the 
Distributive Theory of Military Policy-Making. Western Political Quarterly 24: 620626.

Rundquist, B. S. 1978. On Testing a Military Industrial Complex Theory. American Politics Quarterly 6: 29-53.

Shepsle, K. and Weingast, B. (1981). Political Preferences for the Pork Barrel: A Generalization. American Journal of Political Science 25: 96-111.

Stein, R. M. 1991. "The Allocation of Federal Aid Monies: The Synthesis of a DemandSide and Supply-Side Explanations." American Political Science Review 75: 334-343.

Stone, W.J. 1979. "Measuring Constituency-Representative Linkages: Problems and Prospects." American Journal of Political Science 33: 272-293.

Strom, G. (1975). Congressional Policy Making: A Test of a Theory. Journal of Politics 37: 711-735.

Weingast, B., Shepsle, K., and Johnsen, C. (1981). The Political Economy of Benefits and Costs: A Neoclassical Approach to Distributive Politics. Journal of Political Economy 89: 642-664.

Weingast, B. R. and Marshall, W. J. (1988). The Industrial Organization of Congress: or, Why Legislatures, Like Firms, Are Not Organized as Markets. Journal of Political Economy 96: 132-163.

Weingast, B. R. and Moran, M. J. (1988). Bureaucratic Discretion or Legislative Control? Regulatory Policymaking by the Federal Trade Commission. Journal of Political Economy 91: 765-800.

Wilson, R. (1986). An Empirical Test of Preferences for the Political Pork Barrel: District Level Outlays for River and Harbor Legislation, 1899-1913. American Journal of Political Science 621-649.

Wildavsky, A.B. 1988. The New Politics of the Budgetary Process. Glenview, IL: Scott, Foresman. 